\title{
Note to the Users of Pernkopf's Atlas of Topographical and Applied Human Anatomy
}

The various editions of Pernkopf's Atlas of Topographical and Applied Human Anatomy are based on the original version, Topographische Anatomie des Menschen, published in German in four volumes between 1937 and 1957. Its author, the anatomist Eduard Pernkopf (18881955) was a high-ranking Austrian National Socialist. As dean of the Medical Faculty of Vienna, he was co-responsible for the expulsion of hundreds of Jewish scientists and students from the university. Between 1943 and 1945, he held one of the highest academic positions in Nazi-controlled Austria as rector of the University of Vienna.

What is more, the Vienna Institute of Anatomy, which Pernkopf headed, received during the war the bodies of at least 1377 people executed by the regime, many for their political views or acts of resistance, including at least seven Jewish victims. An investigation commissioned by the University of Vienna in 1997/98 came to the conclusion that in all likelihood, a considerable number of the paintings produced for Pernkopf's Atlas of Topographical and Applied Human Anatomy during and after the war are based on the bodies of these victims. Also, as a symbol of allegiance to National Socialism, some original illustrations were marked with Nazi symbols such as swastikas by the painters. These signs were sometimes retouched in later editions.

Due to the anonymization of the bodies and war-time losses of the original documentation, it is impossible to determine which illustrations in the atlas are based on victims of National Socialist persecution and repression.

Against this background, the publishers (originally Urban \& Schwarzenberg, later acquired by Elsevier) decided to stop both printing Pernkopf's Atlas and licensing the use of its illustrations.

It is our conviction that out of respect for the victims of National Socialist persecution, Pernkopf's Atlas of Topographical and Applied Human Anatomy should preferably no longer be used in medical teaching and training, although the decision ultimately rests with each individual user's responsibility.

Vienna, 1 July 2021

Markus Müller, Rector of the Medical University of Vienna

Christiane Druml, Director of the Department of Ethics, Collections and History of Medicine (Josephinum) and holder of the UNESCO Chair of Bioethics

(Please print and insert this "Note to the Users of Pernkopf's Atlas of Topographical and Applied Human Anatomy” in all volumes.) 